\title{
MEKANISME ANTAGONIS LIMA ISOLAT Bacillus subtilis TERHADAP Colletotrichum capsici DAN C. gloeospoiroides IN VITRO
}

\section{Antagonistic Mechanism of Five Isolates of Bacillus subtilis to Colletotrichum capsici and Colletotrichum gloeospoiroides In Vitro}

\author{
Nur Kholida Wulansari ${ }^{1 *}$, Nur Prihatiningsih ${ }^{2}$, dan Heru Adi Djatmiko \\ ${ }^{1}$ Mahasiswa Pasca Sarjana, Fakultas Pertanian, Universitas Jenderal Soedirman \\ ${ }^{2}$ Staf Pengajar Fakultas Pertanian, Universitas Jenderal Soedirman \\ Jl. dr. Soeparno Purwokerto 53123
}

\begin{abstract}
ABSTRAK
Colletotrichum capsici dan C. gloeospoiroides adalah jamur patogen penting pada cabai merah yang dapat menurunkan produktivitas. Upaya untuk mengatasi permasalahan ini yaitu dengan pengendalian hayati menggunakan Bacillus subtilis. Penelitian ini dilakukan untuk mengetahui daya hambat lima isolat B.subtilis yaitu B46, B209, B211, B298, dan B315 terhadap patogen C. capsici dan C. gloeospoiroides asal tanaman cabai. Percobaan laboratorium dilakukan berdasarkan Rancangan Acak Lengkap dengan 5 ulangan. Pengujian in vitro dilakukan menggunakan teknik dual culture pada medium PDA. Hasil penelitian menunjukkan efektifitas penghambatan C.capsici paling baik pada isolat B209 sebesar 34,25\%. Efektifitas penghambatan $C$. gloeospoiroides pada isolat B211 sebesar 28,89\%. Efektifitas penghambatan berpengaruh pada bobot kering misellium dan morfologi hifa $C$. capsici dan C. gloeospoiroides. Morfologi hifa C. capsici dan C. gloeospoiroides mengalami lisis, menebal, dan membengkak.
\end{abstract}

*Alamat Korespondensi: lisawulansari1989@gmail.com

Kata kunci: C. capsici, C. gloeospoiroides, B. subtilis, antagonistik, daya hambat

\begin{abstract}
Colletotrichum capsici and C. gloeospoiroides are an important pathogen on red chili pepper and caused productivity losses. Biological control using B. subtilis is an attempt to solve the problem. The objectives of this study is to determines the inhibition ability of five B. subtilis isolates, i.e. B46, B209, B211, B298, dan B315 against $C$. capsici and C. gloeospoiroides pathogens from chili pepper. Laboratory experinments arranged in complete randomized design with five replication. Dual culture method used PDA medium on in vitro test. Result showed the best inhibition effectiveness of C.capsici on B209 isolates at 34.25\%. The best inhibition effectiveness of C. gloeospoiroides on B211 isolates at 28,89\%. The inhibition effectiveness affects mycellium dry weight and hypha morphology of C. capsici and C. gloeospoiroides. Hypha morphology of C. capsici and C. gloeospoiroides is lysis, thickening, and swelling.
\end{abstract}

Key words: C. capsici, C. gloeospoiroides, B. subtilis, antagonistic, inhibitor ability

\section{PENDAHULUAN}

Cabai (Capsicum annum L.) merupakan salah satu tanaman sayuran yang penting di Indonesia. Produktivitas cabai mengalami peningkatan dari 8,35 ton/ha di tahun 2014 menjadi 8,65 ton/ha 2015 (Badan Pusat Statistik, 2016). Produktivitas cabai merah di Indonesia akan tetapi masih jauh dari potensinya yang dapat mencapai 12-20 ton/ha (Purwati $d k k$,
2010; Syukur $d k k, 2010)$. Salah satu faktor utama yang menyebabkan rendahnya produktivitas cabai di Indonesia adalah gangguan hama dan penyakit (Semangun, 2000). Antraknosa merupakan penyakit yang dominan pada tanaman cabai yang menyebabkan rendahnya produktivitas cabai di Indonesia (Herwidyarti $d k k$., 2013; Hasyim et al., 2014; Nura dkk., 2015). Kehilangan hasil akibat penyakit 
antraknosa dilaporkan dapat mencapai lebih dari 50\% (Saxena et al. 2016; Palupi $d k k$., 2015).

Antraknosa pada cabai disebabkan oleh genus Colletotrichum, diantaranya yaitu C.capsici dan C. gloeospoiroides (Hasyim et al., 2014). Pengendalian penyakit antraknosa yang dilakukan petani umumnya menggunakan fungisida kontak dan fungisida sistemik secara intensif. Namun penggunaan fungisida secara berlebihan tidak hanya menyebabkan peningkatan biaya produksi tetapi juga mengakibatkan resiko kesehatan petani dan konsumen serta merusak lingkungan (Farid dan Utari, 2010). Oleh karena itu penggunaan biopestisida dari mikroba antagonis mulai dikembangkan salah satunya dengan memanfaatkan bakteri Bacillus sp.

Bacillus sp. adalah bakteri antagonis terhadap beberapa patogen tular tanah dan tular udara (Prihatiningsih $d k k .$, 2014). B. subtilis merupakan salah satu spesies dari Bacillus sp. yang potensial sebagai agens pengendali hayati. B. subtilis diketahui memiliki potensi sebagai agens pengendali hayati beberapa patogen tumbuhan (Slepecky and Henphill, 2006). Kemampuan bakteri B. subtilis sebagai agens hayati berkaitan dengan kemampuannya bersaing untuk mendapatkan nutrisi, menghasilkan senyawa metabolit sekunder seperti antibiotik, siderofor dan enzim ekstraseluler (Soesanto, 2008). B. subtilis diketahui dapat mengendalikan patogen Magnoporthe grisea (Ali and Nadarajah, 2014), Xanthomonas oryzae pv. Oryzae (Wartono $d k k ., 2015)$ dan $R$. solanacearum (Aini dan Abadi, 2004; Prihatiningsih $d k k$., 2015).

Mekanisme pengendalian antagonis B. subtilis adalah dengan persaingan atau kompetisi, antibiosis, parasitisme dan lisis. Mekanisme penekanan dengan persaingan ditunjukkan pada pengujian dengan jamur patogen yang dibiakkan secara ganda dengan memperebutkan ruang, nutrisi, dan oksigen dengan melihat perkembangan patogen dan antagonis. Mekanisme penekanan dengan persaingan ditunjukkan pada pengujian dengan jamur patogen yang dibiakkan secara ganda dengan memperebutkan ruang, nutrisi, dan oksigen dengan melihat perkembanngan patogen dan antagonis tersebut mana yang lebih cepat memenuhi cawan petri dengan diameter $90 \mathrm{~mm}$. Apabila masing-masing antagonis mampu menghambat jamur maka bersifat fungistatik, dan apabila mematikan patogen maka bersifat fungisidal.

Penelitian yang dilakukan telah menghasilkan isolat baru B. subtilis yaitu B46, B209, B211, B298 dan B315 (Prihatiningsih dan Kustantinah, 2005). Isolat B. subtilis ini telah dicobakan untuk pengendalian penyakit layu bakteri di 
kentang (Prihatiningsih $d k k .$, 2015) dan tomat. Pada penelitian ini dilakukan pengujian B. subtilis isolat B46, B209, B211, B298 dan B315 untuk pengendalian penyakit antraknosa pada cabai. Permasalahan yang dihadapi adalah apakah lima isolat B. subtilis (B46, B209, B211, B298 dan B315) mempunyai mekanisme antagonis yang sama atau berbeda dalam menekan pertumbuhan patogen C.capsici dan C. gloeospoiroidesin-vitro. Tujuan dari penelitian ini adalah mempelajari mekanisme lima isolat $B$. subtilis untuk menekan pertumbuhan patogen $C$. capsici dan C. gloeospoiroides in-vitro.

\section{METODE PENELITIAN}

\section{Waktu dan Tempat Percobaan}

Penelitian dilaksanakan di Laboratorium Penyakit Tanaman, Fakultas Pertanian, Universitas Jenderal Soedirman pada bulan Maret sampai September 2017. Antagonis yang digunakan dalam penelitian adalah B. subtilis yang berasal dari isolat murni terdiri dari lima isolat yaitu B46, B209, B211, B298 dan B315 (Koleksi Prihatiningsih). Jamur Colletotricum sp diisolasi dari buah cabai merah besar bergejala antraknosa. Bahan kimia yang digunakan adalah medium biakan PDA (Potato Dextrose Agar) dan NA (Natrium Agar). Penelitian menggunakan Rancangan Acak Kelompok (RAK) faktorial dengan lima ulangan. Faktor yang dicoba adalah dua spesies Colletotricum sp., yaitu $C$. capsici dan C. gloeospoiroides dan lima isolat B. subtilis, yaitu B46, B209, B211, B298 dan B315.

\section{Isolasi dan Perbanyakan $C$. capsici dan} C. gloeospoiroides

Isolasi C. capsici dan $C$. gloeospoiroides dilakukan dengan menumbuhkan cabai yang bergejala antraknosa pada medium PDA (Paramita $e t$ al., 2014; Nurhayati, 2007). Cabai yang bergejala antraknosa dipotong $1 \mathrm{~cm}$, disterilkan dengan alkohol dan dicuci bersih dengan air steril. Selanjutnya, cabai ditanam pada media PDA dan diinkubasi pada suhu ruang. Setelah 7 hari, koloni yang tumbuh dimurnikan dan diamati (Rabha et al., 2014; Onofre and Antoniazzi, 2014). Isolat C. capsici dan C. gloeospoiroides murni diperbanyak pada medium PDA untuk uji antagonistik.

\section{Peremajaan isolat B. subtilis B46, B209, B211, B298 dan B315}

Isolat murni B. subtilis B46, B209, B211, B298 dan B315 masing-masing diperbanyak pada media NA miring dan diinkubasi pada suhu ruang selama 2 hari. Semua pekerjaan dilakukan secara aseptis pada Laminar Air Flow (LAF).

Uji Antagonisme B. subtilis B46, B209, B211, B298 dan B315 terhadap Colletotrichum sp.

Pengujian antagonis B. subtilis terhadap patogen $C$. capsici dan $C$. gloeospoiroides dilakukan pada media PDA 
dual culture (Muthukumar, 2013) menggunakan koloni $B$. subtilis $\mathrm{B} 46 \mathrm{x}$ Colletotrichum sp.,B. subtilisB209 X Colletotrichum sp.,B. subtilisB211 X Colletotrichum sp., B. subtilisB298 x Colletotrichum sp., dan B. subtilis B315 x Colletotrichum sp. Setiap isolatB. subtilis dari medium NA diambil 1 jarum ose di goreskan ke dalam medium PDA sepanjang $3 \mathrm{~cm}$, diinkubasi pada suhu ruang selama 1 hari. Hari berikutnya jamur Colletotricum sp. dipotong dengan diameter $5 \mathrm{~mm}$ diletakkan cawan petri dengan jarak $2,5 \mathrm{~cm}$ dari B. subtilis (Evans et al., 2003; Khadim et al., 2014), kemudian diinkubasi pada suhu kamar. Perlakuan tersebut diulang 5 kali. Variabel yang diamati adalah penghambatan pertumbuhan Colletotricum sp., bobot kering miselium dan studi morfologi miselium. Data penghambatan pertumbuhan dan bobot kering miselium dianalisis menggunakan uji ragam. Jika uji ragam berbeda nyata dilanjutkan dengan uji jarak ganda duncan pada taraf kesalahan $5 \%$.

Penghambatan pertumbuhan $C$. capsici dan C. gloeospoiroides

Pertumbuhan patogen dicatat dan data diperoleh dari persentase penghambatan pertumbuhan jejari dengan rumus (Hyun et al, 2013):

$\mathrm{PP}=\frac{R 1-R 2}{R 1} \times 100$

Keterangan:

$\mathrm{PP}=$ penghambatan pertumbuhan $(\%)$
$\mathrm{R} 1=$ jari-jari koloni patogen yang berlawanan dengan arah antagonis.

$\mathrm{R} 2$ = jari-jari koloni patogen yang mengarah kearah antagonis.

Bobot kering miselium $C$. capsici dan $C$. gloeospoiroides

Bobot kering miselium jamur dihitung pada hari terakhir setelah cawan petri tanpa perlakuan dipenuhi oleh jamur (hari ke-7). Untuk mengukur bobot kering miselium jamur, setiap cawan petri ditambah dengan $10 \mathrm{ml} \mathrm{HCl} \mathrm{1 \%} \mathrm{dan} \mathrm{dipanaskan} \mathrm{dengan} \mathrm{water}$ bath, kemudian disaring dengan menggunakan kertas Whatman steril yang sebelumnya ditimbang bobotnya. Selanjutnya dikeringkan dengan oven pada suhu $60^{\circ} \mathrm{C}$ selama 2 hari dan ditimbang. Bobot kering miselium dapat dihitung dengan rumus:

$\mathrm{BKM}=\mathrm{BKK}-\mathrm{BKP}$

Keterangan :

$\mathrm{BKM}=$ bobot kering miselium

$\mathrm{BKK}=$ bobot kering kontrol

$\mathrm{BKP}=$ bobot kering perlakuan

\section{Studi Morfologi Miselium}

Dilakukan dengan mengamati perkembangan miselium Colletotrichum $\mathrm{sp}$ yang berbatasan dengan B. subtilis. Pengamatan dilakukan pada hari setelah miselium Colletotrichum sp. bersinggungan dengan B. subtilis, dengan melihat penyebaran koloni, arah pertumbuhan koloni, perubahan ujung misellium yang menunjukkan pembengkakan bagianbagian misellium (Martinius et al., 2010). 


\section{HASIL DAN PEMBAHASAN}

Jamur C. capsici dan C. gloeospoiroides ditemukan berasosiasi dengan buah cabai besar yang menunjukkan gejala berupa bercak coklat kehitaman, melekuk ke dalam dan terdapat titik-tik hitam pada bercak. Titik-tik hitam ini merupakan kumpulan seta dan konidium yang akan menyebar dan menginfeksi buah dan tanaman cabai (batang dan daun) (Paramita dkk., 2014; Sudirga, 2016; Kumar et al., 2015).

\section{Isolasi dan Perbanyakan $C$. capsici dan C. gloeospoiroides}

Perkembangan koloni C. capsici pada medium PDA terlihat warna merah kelabu, konidium berukuran panjang 18-23 $\mu \mathrm{m}$ lebar 3,5-4 $\mu \mathrm{m}$, berbentuk bulan sabit (Gambar 1 a-c). Koloni C. gloeospoiroides berwarna putih sampai hitam kelabu, konidium berukuran panjang 9-24 $\mu \mathrm{m}$ lebar 3,5-4 $\mu \mathrm{m}$, berbentuk lurus dengan ujung bulat, hialin (Cano et al. 2014; Santos et al. 2013; Moe and Oh, 2016).

\section{Peremajaan isolat B. subtilis B46, B209, B211, B298 dan B315}

Hasil perbanyakan isolat $B$. subtilis B46, B209, B211, B298 dan B315 yang ditumbuhkan pada medium miring YPGA dan NA dan diinkubasi 2x24 jam menunjukkan koloni yang beragam (Gambar 2). Warna koloni pada umummnya putih susu sampai kekuningan atau putih suram. Tepi koloni tidak rata, permukaan kasar, pada isolat B209, B211, B298 dan B315 tidak berlendir, sedangkan isolat B46 berlendir. Koloni berukuran besar dan tidak mengkilat (Rheinheimer, 1991; Khadim et al., 2014).

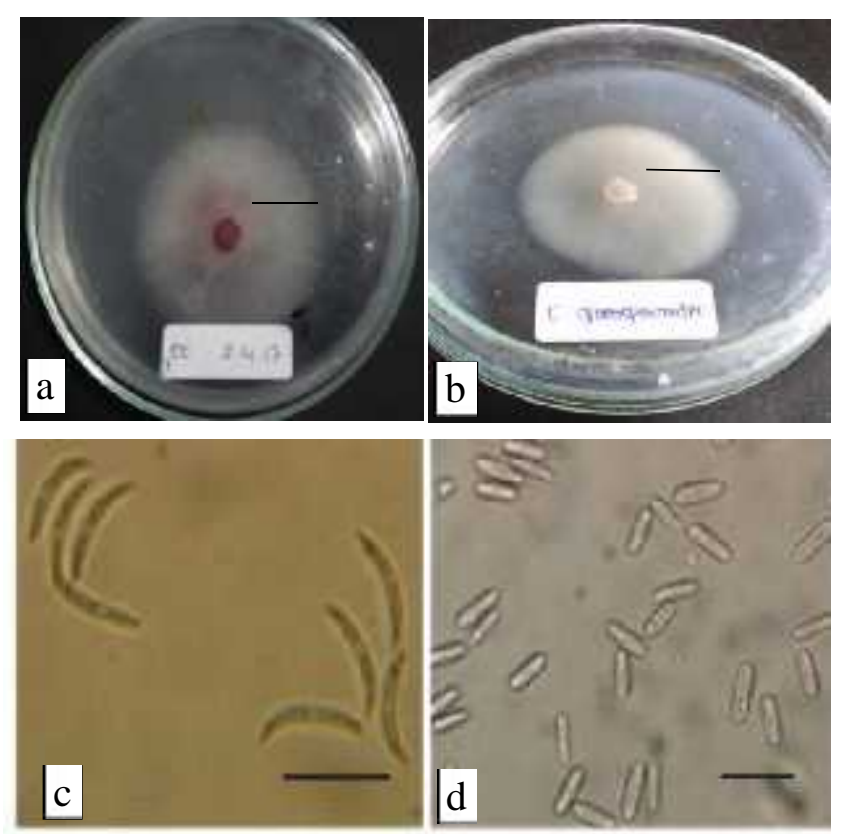

Gambar 1. Hasil pengamatan C. capsici dan C. gloeospoiroides (perbesaran 400x). a.C. capsici pada medium PDA umur 4 hari; b. $C$. gloeospoiroides pada medium PDA umur4 hari; c. konidia jamur $C$. capsici; d. konidia jamur $C$. gloeospoiroides (Sumber: Santos et al., 2013). 


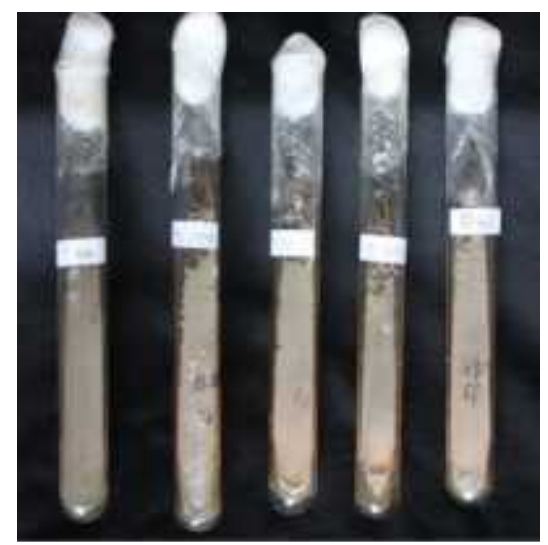

Gambar 2. Isolat B. subtilis yang ditumbuhkan pada medium miring YPGA.

Uji Antagonisme B. subtilis B46, B209, B211, B298 dan B315 terhadap Colletotrichum sp.

Uji antagonisme lima isolat $B$. subtilis dilakukan secara in-vitro masing-masing terhadap C. capsici dan C. gloeospoiroides dan kontrol tanpa isolat Bacillus. Penghambatan Isolat Bacillus B46, B209, B211, B298 dan B315 terhadap C. capsici dan C. gloeospoiroides dapat dilihat pada Gambar 3a dan 3b. Nampak adanya penghambatan pada pertumbuhan $C$. gloeospoiroides dan C. capsici pada hari ke 5. Sedang kontrol tidak mengalami penghambatan, terlihat koloni memenuhi cawan petri (Gambar 3c).

Hasil analisis ragam menunjukkan interaksi antara B. subtilis dan Colletotrichum sp. berbeda nyata pada variabel daya hambat. Artinya daya hambat dipengaruhi oleh $B$. subtilis dan Colletotrichum. Hampir semua isolat $B$. subtilis memiliki potensi menghambat pertumbuhan $C$. capsici dan $C$. gloeospoiroides kecuali pada isolat B46 (Tabel 1). Penghambatan isolat B. subtilis terhadap C. capsici terbaik diperoleh pada isolat B209 (34,25\%) dan B298 (34,00\%) yang berbeda dengan isolat B211 $(23,65 \%)$ dan B315 (23,51\%). Pada penghambata terhadap C. gloeospoiroides, semua isolat memiliki kemampuan yang sama kecuali pada isolat B46.

Tabel 1 menunjukkan isolat B209 dan B298 memiliki daya hambat yang berbeda terhadap C. capsici dan C. gloeospoiroides. Daya hambat isolat B209 dan B298 terhadap C. capsici lebih tinggi dibandingkan dengan daya hambatnya terhadap C. gloeospoiroides. Hasil lain menunjukkan kemampuan daya hambat pada isolat B211 dan B315 terhadap $C$. capsici dan C. gloeospoiroides adalah sama. Namun demikian, isolat B209, B211, B298 dan B315 memiliki daya hambat terhadap C. gloeospoiroides yang sama. Daya hambat isolat B209 dan B298 terhadap C. gloeospoiroides lebih kecil dibandingkan dengan C. capsici karena perkembangan C. gloeospoiroides lebih cepat dan lebih virulen (Phouliving, 2011). 


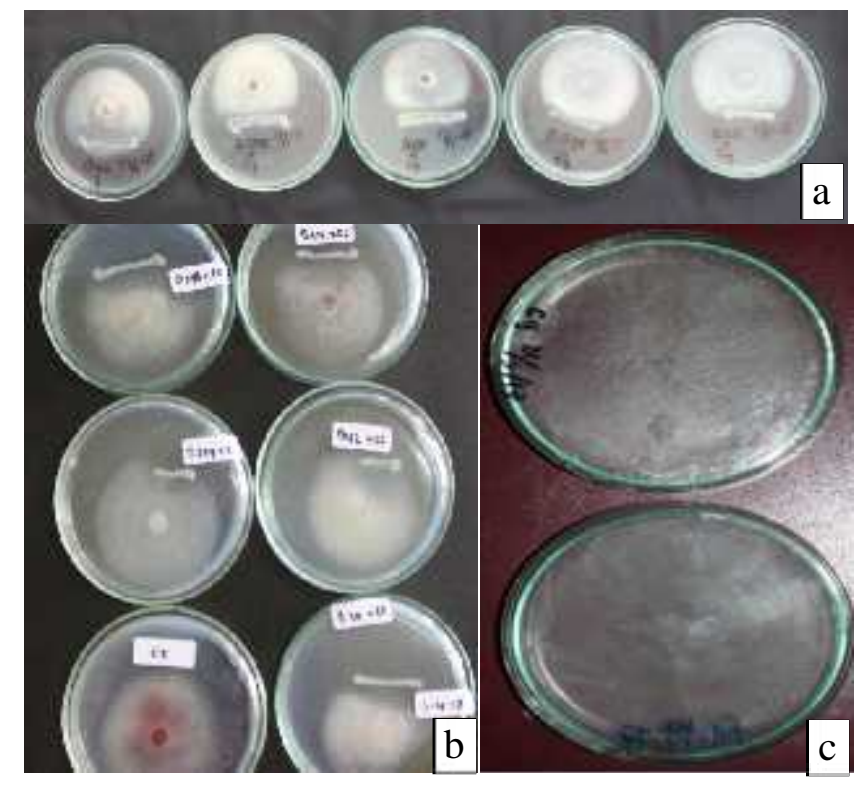

Gambar 3. Uji Dual Culture. A. Isolat B46, B209, B211, B298 dan B315 dengan C. gloeospoiroides., B. Isolat B46, B209, B211, B298 dan B315 dengan C. capsici., C. Kontrol C. gloeospoiroides dan C. capsici.

Tabel 1. Daya hambat (\%) lima isolat B. subtilis terhadap Colletotrichum sphari ke 5 setelah inokulasi

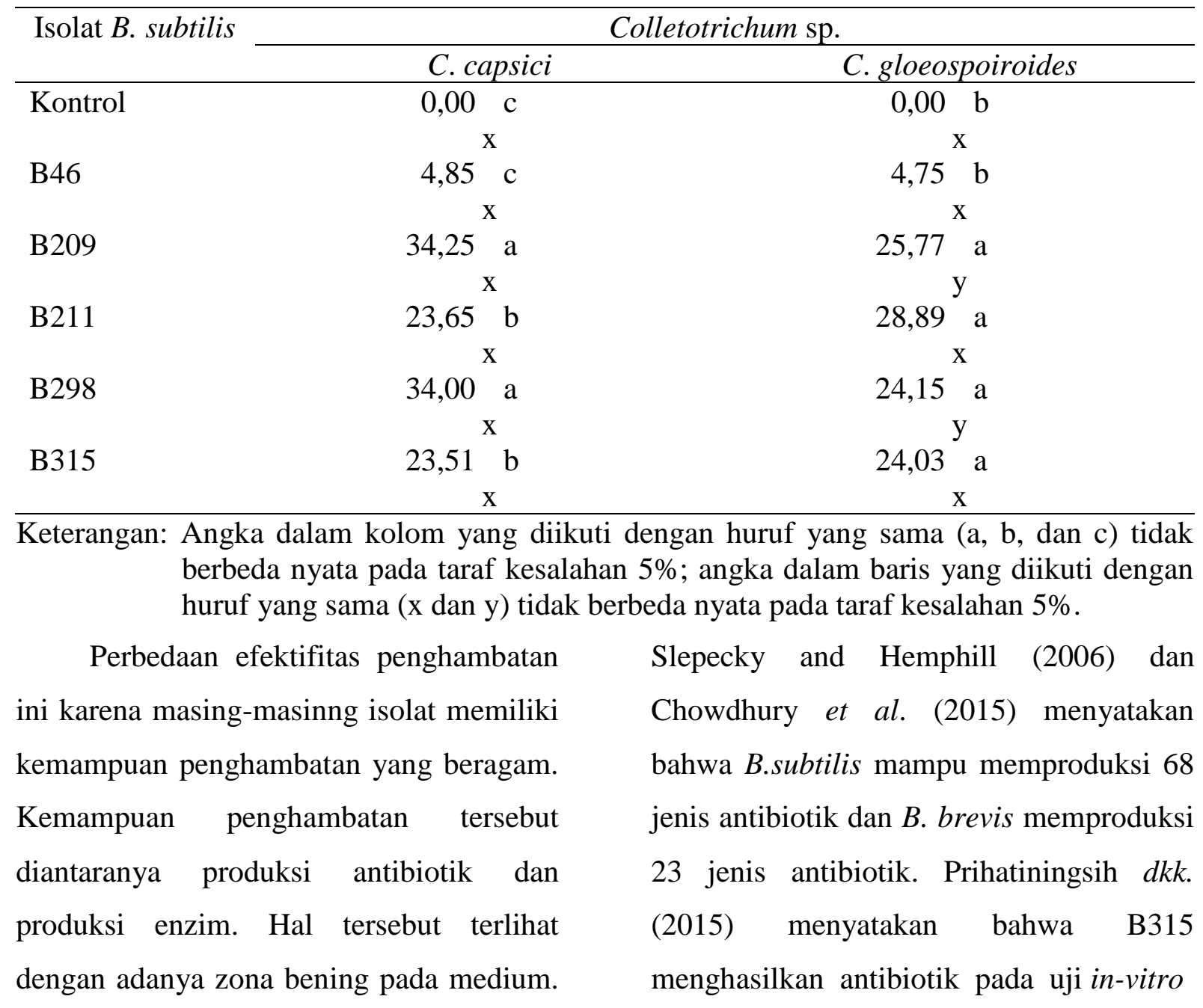


Tabel 2. Bobot kering misselium (g) C. capsici dan C. gloeospoiroides pada perlakuan isolat B. subtilis

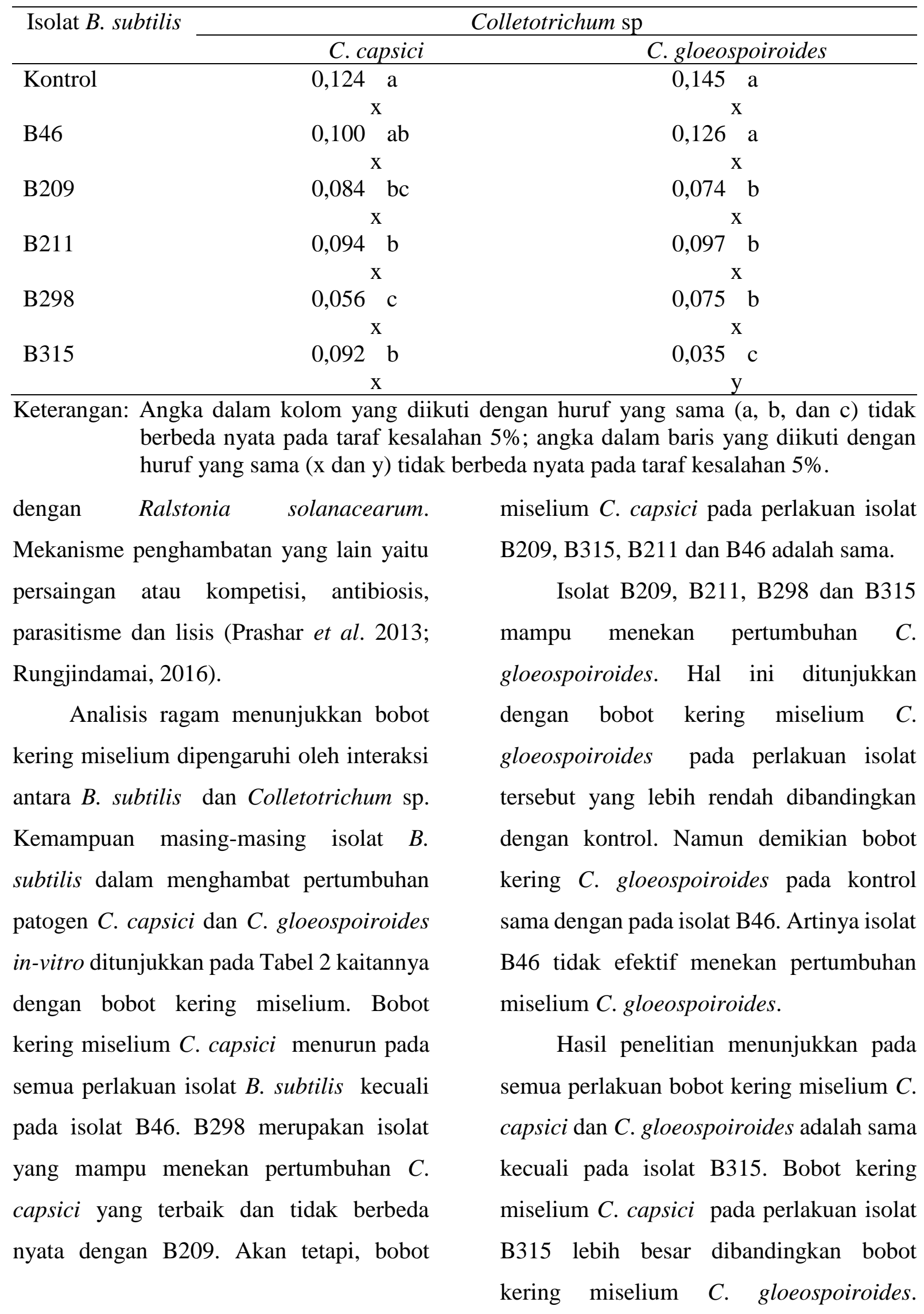


Artinya isolat B315 lebih efektif terhadap

C. gloeospoiroides pada pengujian in vitro.

Perbedaan kemampuan isolat-isolat B. subtilis di dalam menghambat pertumbuhan dan bobot kering misellium jamur patogen diduga disebabkan oleh keragaman yang tinggi antar isolat $B$. subtilis, sesuai dengan pendapat Bais et al. (2004). Strain B. subtilis memilki kemampuan menghambat patogen yang beragam karena memiliki antibiotik yang berbeda, seperti surfaktin, bacilysin, subtilin, subtilosin, fengisin. B. subtilis juga menghasilkan enzim kitinase yang dapat menghambat dan mendegradasi kitin pada dinding sel jamur sehingga jamur mengalami lisis (Rahayuniati dan Mugiastuti, 2012). Kemampuan isolat $B$. subtilis dalam mendegradasi dinding sel $C$. capsici dan C. gloeospoiroides dapat dillihat pada Gambar 4 dan 5.
Gambar 4. menunjukkan morfologi hifa C. capsici mengalami kerusakan berupa penebalan dan pembengkakan hifa akibat perlakuan isolat $B$. subtilis, berbeda dengan kondisi normal atau kontrol. Pada kontrol, hifa nampak lurus dan bercabang tanpa kerusakan. Pembengkakan hifa diperoleh pada C. capsici yang ditumbuhkan pada perlakuan isolat B209, B211, B298 dan B315. Pada perlakuan isolat $\mathrm{B} 46, C$. capsici hanya mengalami penebalan hifa.

C. gloeospoiroides mengalami kerusakan berupa penebalan, dan lisis. Pada kondisi normal atau kontrol, hifa $C$. gloeospoiroidesnampak lurus dan bercabang tanpa kerusakan (Gambar 5). Hifa C. gloeospoiroides pada perlakuan isolat B46 dan B209 mengalami penebalan. Isolat B315 menyebabkan hifa $C$. gloeospoiroides menebal dan membengkak.

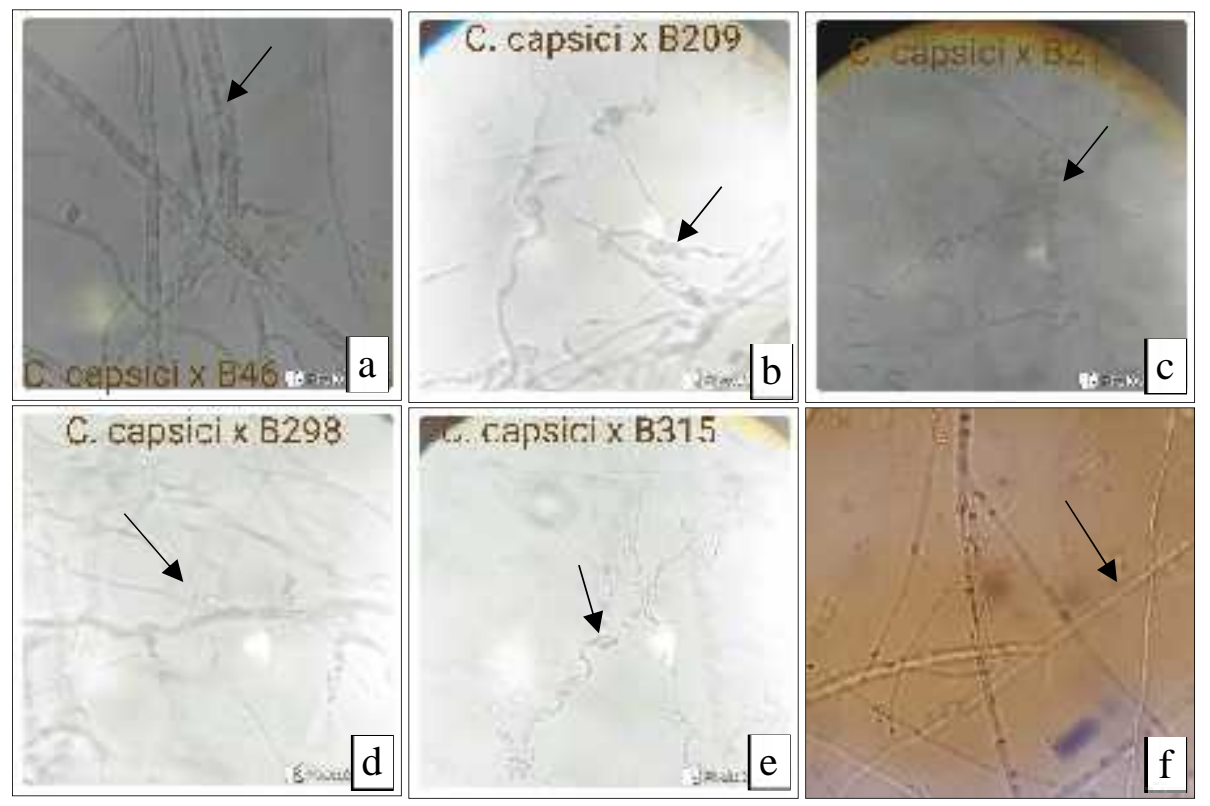

Gambar 4. Morfologi hifa C. capsicipada perlakuan isolat B. subtilis . (a) Menebal, (b-c-e) Membengkak, (d) lisis dan f. Normal. 


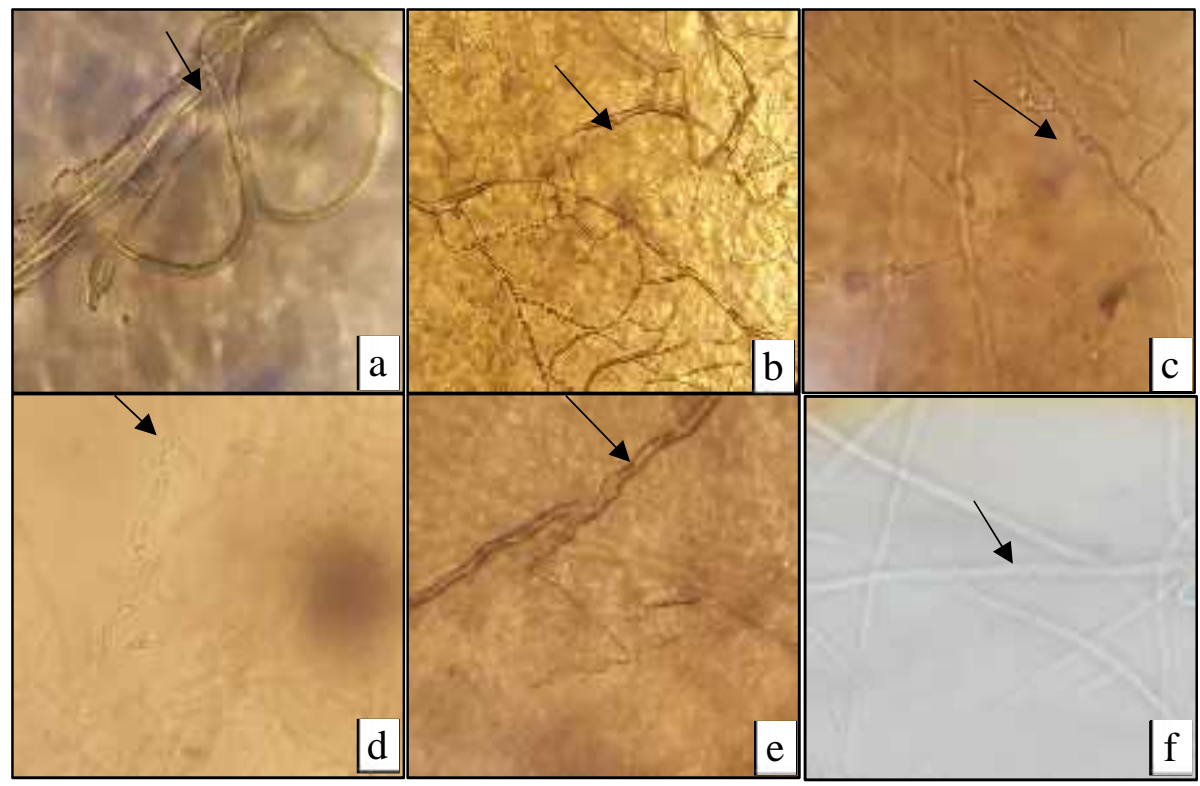

Gambar 5. Morfologi hifa C. gloeospoiroidespada perlakuan isolat B. subtilis . a. Isolat B46, b. Isolat B209, c. Isolat B211, d. Isolat B298, e. Isolat B315 dan f. Kontrol (tanpa isolat B. subtilis ). (a,b,c,e) Menebal, (d) Lisis, (f) Normal.

Isolat B315 menyebabkan hifa $C$. gloeospoiroides menebal dan membengkak. Hifa C. gloeospoiroides mengalami lisis pada perlakuan isolat B211 dan B298.

Miselium mengalami penghambatan pertumbuhan karena kerusakan yang disebabkan adanya mekanisme isolat $B$. subtilis. B. subtilis diketahui menghasilkan metabolit sekunder seperti pyrrolnitrin, penazine and cepabactin yang dapat mempengaruhi pertumbuhan dan morfologi misellium (Rahman et al., 2007; Cartwright et al., 1995). B. subtilis menghasilkan antibiotik yang dapat menembus sel patogen dan menghambat aktivitas patogen yang menyebabkan kerusakan sel dan hifa (Moreira et al., 2014). B. subtilis juga memproduksi dan mensekresikan siderofor dan hidrogen sianida yang beracun bagi patogen (Wang et al., 2009; Ali and Nadarajah, 2014).

\section{KESIMPULAN}

Lima isolat $B$. subtilis mampu menghambat pertumbuhan $C$. capsici dan C. gloeospoiroides. Isolat B209 memiliki efektifitas penghambatan terbaik pada $C$. capsici, sedangkan pada C. gloeospoiroides isolat yang memiliki penghambatan terbaik yaitu B315. Perlakuan isolat B. subtilis menyebabkan morfologi hifa $C$. capsici dan C. gloeospoiroides mengalami lisis, menebal, dan membengkak.

\section{UCAPAN TERIMA KASIH}

Ucapan terima kasih diucapkan kepada Kementerian Riset, Teknologi dan Pendidikan Tinggi yang telah membiayai penelitian ini.

\section{DAFTAR PUSTAKA}

Aini, L. Q. dan A. L. Abadi. 2004. Keragaman bakteri endofit dalam 
jaringan akar tanaman pisang serta potensi antagonistiknya terhadap bakteri patogen penyebab penyakit layu pada tanaman pisang. Jurnal Ilmu-Ilmu Hayati, 16(2): 113-124.

Ali, H. and K. Nadarajah. 2014. Evaluating the efficacy of Trichoderma spp and Bacillus subtilis as biocontrol agents against Magnapothe grisea in rice. Australian Journal of Crop Science, 8(9): 1324-1335.

Badan Pusat Statistik. 2016. Produksi cabai besar menurut provinsi, 2010-2016. Badan Pusat Statistik dan Direktorat Jenderal Hortikultura.

Bais, H.P., R. Fall, and J. M. Vivanco. 2004. Biocontrol of Bacillus subtilis against infection of arabidopsis Roots by Pseudomonas syringae is facilitated by biofilm formation and surfactin production. Plant Physiology, 134: 307-319.

Cartwright, D.K, W. S. Chilton dan D.M. Benson. 1995. Pyrrolnitrin and phenazine production by Pseudomonas cepacia, strain 5.5B, a biological agent of Rhizoctonia solani. Applied Microbiology Biotechnology, 43(2): 211-216.

Cano, J., J. Guarro, and J. Gene. 2014. Molecular and morphological identification of Colletotrichum species of clinical interest. Jurnal of Clinicalogy Microbiol, 42(6): 24502454.

Chowdhury, P.S., A. Hartmann, X. W. Gao and R. Borriss. 2015. Biocontrol mecanism by root-asoosiated Bacillusamyloliquefaciens FZ-B42. Frontiers in Microbiology, 6(780): 111.

Evans, H.C., K.A. Holmes, and S.E. Thomas. 2003. Endophytes and mycoparasites associated with an indigenous forest Tree, Theobroma gileri, in Ecuador and a preliminary assessment of their potential as biocontrol agens of cocoa disease. Mycologycal progress, 2: 149-160.

Farid, N., dan D. S. Utari. 2010. Genetika sifat ketahanan cabai merah terhadap virus ChiVMV. Jurnal Agrin, 14(2): $148-158$.

Hasyim, A., W. Setiawati and R. Sutarya. 2014. Screening for resistance to anthracnose caused by Colletotrichum acutatum in chili pepper (Capsicum annuum L.) in Kediri, East Java. AAB Bioflux, 6(2): $104-118$.

Herwidyarti, K. H., S. Ratih dan D. R. J. Sembodo. 2013. Keparahan penyakit antraknosa pada cabai (Capsicum annuит L) dan berbagai jenis gulma. Jurnal Agrotek Tropika, 1(1): 102106.

Hyun, S.J., N.C. Paul, J.X. Deng, Y.S. Kim, B.S. Yun dan S.H. Yu. 2013. Biocontrol activity of bacillus amyloliquefacients CNU114001 against fungal plant diseases. Mycrobiology, 41(4): 243-242.

Khadim, M., P.A. Mihardjo dan A. Majid. 2014. Efektivitas beberapa isolat Bacillus spp. untuk mengendalikan patogen jamur Rhizoctonia solani pada tanaman kedelai. Berkala Ilmiah Pertanian, 10(10): 1-10.

Kumar, S., V. Kumar and V. Singh. 2015. Interaction of Colletotrichum capsici in chilli variety. Life Sciences Leaflet: $41-48$.

Martinius, Y. Liswarni, dan Y. Miska. 2010. Uji konsentrasi rebusan daun serai wangi Andropogon nardus L. (Graminae) terhadap pertumbuhan jamur

Colletrotichum gloeosporiodies Penz. penyebab penyakit antraknosa pada pepaya secara in vitro. Manggaro, 11(2): 5764.

Moe, M. O., and S. K. Oh. 2016. Chilli antracnose (Colletotrichhum spp.) disease and its management approach. 
Korean Journal of Agricultural Science, 43(2): 153 - 162.

Moreira, R.R., C. Nunes, and L. Larissa. 2004. Bacilus spp. and Pseudomonas putida as inhibitors of the Colletotrichum acutatum group and potential to control Glomerella leaf spot. Biological Control, 72: 30-37.

Muthukumar, A. and A. Venkatesh. 2013. Exploitation of fungal and endophytic bacteria for the management of leaf blight of ribbon plant. J. Plant. Pathol. Microb, 4(10): 2-5.

Nura, M. Syukur, N. Khumaida dan Widodo. 2015. Radiosensitivitas dan heritabilitas ketahanan terhadap penyakit antraknosa pada tiga populasi cabai yang diinduksi iradiasi sinar gamma. Jurnal Agronomi Indonesia, 43(3): 201 - 206.

Nurhayati. 2007. Pertumbuhan Colletotrichum capsici penyebab antraknosa buah cabai pada berbagai media yang mengandung extrak tanaman. Jurnal Rafflesia, 9(1): 1411-2434.

Onofre, S.B. and D. Antoniazzi. 2014. Behavior of the fungus Colletrotichum gloeosporioides (Penz \& Sacc.), which causes bitter rot in apples after harvesting. Advances in Microbiology, 4: 202 206.

Palupi, H., I. Yulianah dan Respatijarti. 2015. Uji ketahanan 14 galur cabai besar (Capsicum annuum L.) terhadap penyakit antraknosa (Colletotrichum spp) dan layu bakteri (Ralstonia solanacearum). Jurnal Produksi Tanaman, 3(8): 640-648.

Paramita, N. R., C. Sumardiyono, dan Sudarmadi. 2014. Pengendalian kimia dan ketahanan Colletotrichum spp. terhadap fungisida simoksanil pada cabai merah. Jurnal Perlindungan Tanaman Indonesia, 18(1): 41-46.
Phouliving. 2011. Colletotrichum, naming, control, resistance, biocontrol of weeds and current chalenges. Current Research in Eviromental \& Applied Mycology, 1(1): 53-73.

Prashar, P., N. Kapoor, and S. Sachdeva. 2013. Isolation and characterization of Bacillus $s p$ with In-vitro antagonistic activity against Fusarium oxysporum from rhizosphere of tomato. Journal Agricultural Science and Technology, (15):1501-1512.

Prihatiningsih, N., dan Kustantinah. 2005. Uji penerapan lima isolat Bacillus sp. asal rizosfer kentang terhadap Raslstonia solanocearum, pertumbuhan dan hasil tanaman tomat. Jurnal Agrin, 9(1): 121 - 129.

Prihatiningsih, N., T. Arwiyanto, B. Hadisutrisno dan J. Widada. 2014. Seleksi mutan antibiosis Bacillus subtilis B315 untuk pengendalian Ralstonia solanacearum Pr7. Jurnal Agrin, 18(1): 67 - 79.

Prihatiningsih. 2015. Mekanisme antibiosis Bacillus subtilis B315 untuk mengendalikan penyakit layu bakteri kentang. Jurnal HPT Tropika, 15(1): 64-71.

Purwati, E., B. Jaya dan A.S. Duriat. 2000. Penampilan beberapa varietas cabai dan uji resistensi terhadap penyakit virus kerupuk. Jurnal Hortikultura, 10:88-94.

Rabha, A. J., Gauri, D. S., Vijay. V., Ashok, N., and Hemant, K. G. 2014. In Vitro Evaluation of Antagonism of Endophytic Colletotrichum gloeosporioides Against Potent Fungal Pathogens of Camellia sinensis. Indian $J$ Microbiol. 54(3):302-309.

Rahayuniati, R.F. dan E. Mugiastuti. 2012. Keefektifan Bacillus sp. dan Pseudomonas fluorescens mengendalikan Fusarium oxysporum 
f.sp. lycopersici dan Meloidogyne sp. penyebab penyakit layu pada tomat secara in vitro. Jurnal Pembangunan Pedesaan, 12(1): 65 - 70.

Rahman, M.A, J. Kadir, T.M.M Mahmud, R. A. Rahman dan M.M Begum. 2007. Screening of Antagonistic Bacteria for Biocontrol Activitie o Colletotrichum gloeospoiroides in Papaya. Asian Journal of Plant Sciences, 6 (1): 12-20.

Rheinheimer, G. 1991. Aquatic Microbiology. John Wiley \& Sons, Incorporated. Murray Media, German.

Rungjindamai, N. 2016. Isolation and evaluation of biocontrol agent in controllinng antracnose disease of mango in Thailand. Journal of Plant Protection Research, 56(3): 306 311.

Santos, G. R., Hugo J. T. J., Danila A. C.d. S., Gleiber., Quintão. F., and Nelson S.M. J. 2013. Etiology and pathogenicity of two different isolates of Colletotrichum spp. obtained from physic nut seeds. Journal of Seed Science, 35 (2):139-146.

Saxena, A., R. Raghuwanshi, V. K. Gupta, and H. B. Singh. 2016. Chilli Anthracnose: The Epidemiology and Management. Frontiers in Microbiology.

Semangun, H. 2000. Penyakit-Penyakit Tanaman Hortikultura di Indonesia. Ed ke-4. Gajah Mada University Press, Yogyakarta. 850 hal.
Slepecky, R.A., and H.R. Henphill. 2006. The Genus Bacillus-Nonmedical. Di dalam: Balows A, Trupper HG, Dworkin M, Harder W, Schleifer KH, editor. The Prokaryotes. Ed. ke-2. Springer-Verlag, New York. p. 16631696.

Soesanto, L. 2008. Pengantar Pengendalian Hayati Penyakkit Tanaman. Raja Grafindo Persada, Jakarta. 574 hal.

Sudirga, K. 2016. Isolasi dan identifikasi jamur Colletotrichum spp. isolat PCS penyebab penyakit antraknosa pada buah cabai besar (Capsicum annum L.) di Bali. Jurnal Metamorfosa, 3(1): 23-30.

Syukur, M., S. Sujiprihati, R. Yunianti, dan D. A Kusumah. 2010. Evaluasi daya hasil cabai hibrida dan daya adaptasinya di empat lokasi dalam dua tahun. Jurnal Agronomi Indonesia, 38(1): 43-51.

Wang, H., Wen, K., Zhao, Wang, X., Li, A., and Hong, H. 2009. The inhibitory activity of endophytic Bacillus sp. strain CHM1 against plant pathogenic fungi and its plant growth-promoting effect. Crop Protection, 28(8): 634639.

Wartono, Giyanto dan K. H. Mutaqin. 2015. Efektivitas formulasi spora Bacillus subtilis B12 sebagai agen pengendali hayati penyakit hawar daun bakteri pada tanaman padi. Penelitian Pertanian Tanaman Pangan, 34(1): $21-28$. 